\title{
Hepatitis C RNA prevalence in a Western European organ donor pool and virus transmission by organ transplantation
}

\author{
D. CANDINAS, HELEN I. JOLLER-JEMELKA* R. SCHLUMPF, A. WICKI†, \\ D. J. MUTIMER $\ddagger$, G. KEUSCH* ${ }^{*}$ and F. LARGIADĖR
}

Departments of Surgery and *Internal Medicine, University of Zurich Hospital, Zurich, $\uparrow$ ANAWA Laboratories, Wangen, Switzerland and $\ddagger$ Liver Unit, Queen Elizabeth Hospital, Edgbaston, Birmingham B15 2TH

\begin{abstract}
Summary. Liver disease is a common finding after organ transplantation and might in part be due to transmission of hepatitis $\mathrm{C}$ virus (HCV). The aim of this study was to determine the prevalence of positive results with different anti-HCV tests and HCV-RNA in a local donor pool and to clarify to what extent $\mathrm{HCV}$ was transmitted to organ recipients. Serum samples from 207 consecutive organ donors were analysed retrospectively with anti-HCV ELISA (2nd and 3rd generation), anti-HCV RIBA (2nd generation) and HCV polymerase chain reaction (PCR). Organ recipients at risk were identified and followed up serologically and clinically. Anti-HCV seroprevalance in organ donors was $4.3 \%$ for 2nd generation ELISA, $4.8 \%$ for 3rd generation ELISA and $1.9 \%$ for 2nd generation RIBA. HCV-PCR was positive in $1.4 \%$. Nine organs from four RIBA-positive donors were transplanted into eight recipients of whom four became anti-HCV and PCR positive after transplantation. HCV-PCR became positive several days after transplantation whereas anti-HCV seroconversion took place after 8-9 months. Two recipients developed acute liver disease and another two showed features of mild chronic liver disease but no serious complications due to $\mathrm{HCV}$ infection were observed.
\end{abstract}

\section{Introduction}

Viruses are an important cause of liver disease in organ transplant recipients. Herpes viruses such as cytomegalovirus, herpes simplex and Epstein-Barr viruses, the human immunodeficiency virus, hepatitis viruses $\mathrm{A}, \mathrm{B}$ and $\mathrm{D}$, the human T-cell lymphotropic virus type 1 and the protozoa Toxoplasma gondii may be transmitted by transplanted organs from the donor to the recipient. ${ }^{1}$ Furthermore, shortly after its detection in $1989,{ }^{2}$ the hepatitis C virus (HCV) was recognised as belonging to the increasing list of microbiological agents known to be transmitted in this way. Several studies ${ }^{3-5}$ helped to clarify the impact of $\mathrm{HCV}$ on liver disease after transplantation, and it became clear that $\mathrm{HCV}$ can be transmitted by organ donation and cause post-transplant liver disease. Since there are considerable geographic differences ${ }^{6-9}$ in $\mathrm{HCV}$ prevalence and in HCV subtypes, ${ }^{10}$ the aim of this study was to identify the prevalence of anti-HCV antibodies and the HCV genome determined by polymerase chain reaction (PCR) in the donor pool of

Received 14 March 1994; revised version accepted 5 May 1994. the Zurich University Hospital, which we assume is representative of this part of Western Europe. Based on these findings, we also attempted to determine to what extent $\mathrm{HCV}$ transmission by solid organ transplantation occurred and how HCV infection developed in organ recipients.

\section{Materials and methods}

To assess anti-HCV and HCV-RNA prevalence, serum samples from 207 consecutive cadaveric organ donors whose organs were transplanted at the Zurich University Hospital between Sept. 1, 1986 and Dec. 31, 1992 were analysed retrospectively. In order to restrict the study to a defined geographical area, only sera from organ donations in Switzerland were analysed and sera from donor organs shipped from abroad were excluded from the study. Sera from potential donors whose organs (for whatever reason) were not suitable for transplantation were also excluded. Sera were stored at $-70^{\circ} \mathrm{C}$. A 2nd generation ELISA was used to detect anti-HCV antibodies (HCV ELISA 2.0 Test System, Ortho 
Table I. Summary of HCV test results in 207 consecutive cadaveric organ donors

\begin{tabular}{lccc}
\hline Test & $\begin{array}{c}\text { Number }(\%) \text { of } \\
\text { positive donors } \\
(\mathrm{n}=207)\end{array}$ & $\begin{array}{c}\text { Number of } \\
\text { positive donors } \\
\text { anti-HCV RIBA } \\
\text { confirmed }\end{array}$ & $\begin{array}{c}\text { Number }(\%) \text { of } \\
\text { anti-HCV } \\
\text { confirmed positive } \\
\text { and HCV-RNA } \\
\text { negative donors }\end{array}$ \\
\hline $\begin{array}{l}\text { Anti-HCV ELISA } \\
\text { 2nd generation }\end{array}$ & $9(4 \cdot 3 \%)$ & $4^{*}$ & $1(0.5 \%)$ \\
$\begin{array}{l}\text { Anti-HCV ELISA } \\
\text { 3rd generation }\end{array}$ & $10(4.8 \%)$ & $4^{*}$ & $1(0.5 \%)$ \\
HCV RNA (PCR) & $3(1.4 \%)$ & $3^{*}$ & - \\
\hline
\end{tabular}

* Same donors.

Diagnostic Systems, Raritan, NJ, USA), and positive test results were confirmed by a 2 nd generation strip immunoblot assay (RIBA HCV Test System, Chiron, Emeryville, CA, USA). Sera were also tested with a 3rd generation ELISA (HCV ELISA 3.0 Test System, Ortho Diagnostic Systems). All sera were screened for HCV genome by PCR with nested primers as described by Garson. ${ }^{11}$ Organ recipients receiving an organ from a confirmed anti-HCV-positive donor were identified in the transplant registry and all available information regarding their pre-operative liver tests was compiled. Recipients' clinical records were checked for preoperative liver disease - defined as any disturbance in liver function tests lasting longer than 2 months - and for peri-operative blood transfusions. None of the organ recipients at risk had any evidence of pretransplantation liver disease but all had received blood transfusions perioperatively. Routinely collected preand post-operative recipient sera were analysed with 2nd generation anti-HCV tests and PCR. Recipients at risk were followed prospectively with tests of liver function. All recipients were vaccinated preoperatively against hepatitis B (HBV) and donor and recipient sera were screened for $\mathrm{HBV}$ markers. Acute post-operative liver disease was defined as an increase in serum levels of alanine aminotransferase to more than 2.5 times the upper limit of normal (normal level $<35 \mathrm{U} / \mathrm{L}$ ) lasting $<6$ months. Chronic liver disease was defined by a persistent elevation of the serum alanine aminotransferase level for $>6$ months. As none of the patients followed up had symptomatic liver disease, biopsies were not justifiable and, therefore, were not performed.

\section{Results}

\section{$H C V$ prevalence in the donor pool}

The sera of nine $(4.3 \%)$ of 207 donors gave positive results with 2 nd generation anti-HCV ELISA. Four of these nine sera ( $1.9 \%$ of all 207 donors) were confirmed as anti-HCV-positive with the Chiron RIBA antiHCV strip immunoblot confirmation assay. All four sera reacted with $\mathrm{c} 22, \mathrm{c} 33$ and $\mathrm{c} 100 \mathrm{HCV}$ proteins. The remaining five sera of the nine repeatedly anti-HCV ELISA-positive donor sera showed no detectable bands in Chiron RIBA anti-HCV. Three $(1.4 \%$ of all sera) of the four RIBA-confirmed anti-HCV positive donors were also HCV-RNA positive as determined by PCR. Two hundred and four donor sera were HCV-RNA negative. Hence, one of four anti-HCV RIBA-confirmed positive donors with no detectable viraemia was PCR negative.

All 207 donor sera were re-tested with 3rd generation Ortho anti-HCV ELISA. Ten $(4.8 \%)$ of 207 donors gave repeatedly positive results; nine of them were also positive in 2 nd generation anti-HCV tests. One donor serum was $3 \mathrm{rd}$ generation anti-HCV ELISA- positive but 2nd generation anti-HCV ELISA-negative and also gave negative results in antiHCV RIBA and HCV-RNA tests. A summary of the serological profiles of donor sera is given in table $\mathrm{I}$.

\section{Transmission of $\mathrm{HCV}$}

Of the four anti-HCV RIBA confirmed positive donors, nine organs (six kidneys, two hearts and one pancreas), were transplanted into eight recipients. None of the recipients had any evidence for pretransplant liver disease and all recipients gave negative results before transplantation for anti-HCV and $\mathrm{HCV}$ RNA. All were HBsAg-negative and anti-HBs positive, reflecting vaccination against $\mathrm{HBV}$. In six recipients, prospective serological and clinical followup was possible and in two recipients $(\mathrm{K} 1, \mathrm{~K} 2)$ no follow-up sera were available and evaluation was, therefore, based on biochemistry results and clinical records only. Four of these six recipients at risk with full serological follow-up gave anti-HCV positive results after transplantation and four of six were also HCV-RNA positive. After a median follow-up of 32 months (range 4-72 months), acute liver disease was observed in two $(\mathrm{H} 2, \mathrm{~K} 5)$ of eight patients at risk and mild asymptomatic chronic liver disease developed in two other patients (K3, K4). Table II summarises the observations in the patients at risk.

\section{Serological follow up}

During the study period, two kidneys were transplanted from a donor (D4) whose anti-HCV and HCV RNA test results were discovered to be positive on the 
Table II. Summary of $\mathrm{HCV}$ test results and clinical follow-up in donor/recipient combinations at risk for $\mathrm{HCV}$

\begin{tabular}{ccccccccc}
\hline $\begin{array}{c}\text { Donor } \\
\text { no. }\end{array}$ & Anti-HCV & PCR & $\begin{array}{c}\text { Recipient } \\
\text { no. }\end{array}$ & Anti-HCV & PCR & $\begin{array}{c}\text { Follow up } \\
\text { (months) }\end{array}$ & $\begin{array}{c}\text { Liver } \\
\text { disease }\end{array}$ & Status \\
\hline D1 & pos & neg & K 1 + P) & ND & ND & 4 & No & Died of sepsis \\
& & & K2 & ND & ND & 72 & No & Alive \\
D2 & pos & pos & H2 & neg & neg & 41 & Acute & Alive \\
D3 & pos & pos & K3 & pos & pos & 32 & Chronic & Alive \\
& & & K 4 & pos & pos & 32 & Chronic & Alive \\
D4 & pos & pos & K 5 & pos & pos & 26 & Acute & Alive \\
& & & K6 & pos & pos & 26 & No & Alive \\
\hline
\end{tabular}

$\mathrm{D}$, organ donor; $\mathrm{K}$, kidney recipient; $\mathrm{P}$, pancreas recipient; $\mathrm{H}$, heart recipient; $\mathrm{ND}$, test not done.

day after transplantation. The donor had normal liver function tests and no history of liver disease was known. Pre-operatively, both recipients (K5, K6) did not have any evidence of liver disease and gave negative results for anti-HCV and HCV-RNA. One recipient (K5) showed an isolated increase in alanine aminotransferase reaching a maximum of $290 \mathrm{U} / \mathrm{L}$ between day 10 and day 20 after transplantation. Apart from this one occurrence, both recipients showed no post-transplantation liver disease. Both were tested at least monthly for anti-HCV and for HCV-RNA for the first 12 months. Two and 12 days after transplantation HCV-RNA was detectable by PCR and persisted for the duration of follow up whereas anti-HCV seroconversion took place only 8 and 9 months after transplantation and persisted in the subsequent controls.

\section{Discussion}

The prevalence of hepatitis $\mathrm{C}$ virus in the population depends among other things, on geographical and socio-economic elements. ${ }^{12,13}$ In Switzerland, a confirmed anti-HCV prevalence among healthy volunteer blood donors of $0 \cdot 3 \%$ has been reported ${ }^{14}$ and in the local organ donor pool, an anti-HCV prevalence of $1.9 \%$ was found. This finding is similar to reports from North America where an anti-HCV prevalence among organ donors of $1.8 \%$ was reported. ${ }^{3}$ The finding that anti-HCV prevalence is higher among organ donors than among healthy blood donors reflects the fact that organ donors are more likely to belong to socioeconomic risk groups for $\mathrm{HCV}$ infection.

Four of nine 2nd generation ELISA positive test results in donors were confirmed by RIBA, and three of four RIBA-confirmed results were also PCR positive. In terms of $\mathrm{HCV}$ transmission from the organ donor to the recipient, detectable viraemia appears to be the crucial finding. In this study, HCV transmission occurred through PCR positive donors only. However, due to the small number of recipients at risk, no conclusion in terms of organ specificity of $\mathrm{HCV}$ transmission can be drawn from this study.

Many studies have shown that RIBA positivity is strongly correlated to $\mathrm{HCV}$ viraemia and with the occurrence of $\mathrm{HCV}$ infection in the recipient. Therefore, we propose that a confirmation test with an immunoblot assay should be used to prevent organ wastage and this study suggests that the rate of anti$\mathrm{HCV}$ positive, non-viraemic donors could be reduced to $0.5 \%$ by the use of a confirmation test. The disadvantages of such a policy, in particular the additional cost for the test kit and the time required to perform the test are justifiable, in our view, considering the increasing need for donated organs. The absence of HCV-RNA positive but anti-HCV negative test results in the investigated donors proves that confirmed 2nd generation anti-HCV tests can be used safely for an assessment of the donor's HCV status.

However, assessing the HCV status in immunocompromised people might be more complex, as illustrated by the findings in patients $\mathrm{K} 5$ and K6 - where HCV-RNA was detectable within a few days of transplantation, whereas seroconversion occurred several months later without any association with clinical symptoms. In contrast, seroconversion in non-immunosuppressed people is known to take place in the first few weeks ${ }^{12,15}$ after viral infection. This finding supports the hypothesis that immunosuppression alters the ability to mount an immune response against $\mathrm{HCV}$ infection, not only following liver transplantation ${ }^{16}$ but also following kidney transplantation.

As has been outlined by others ${ }^{3-5}$ and confirmed by our observations, $\mathrm{HCV}$ infection can be transmitted by solid organ transplantation and cause acute and chronic liver disease in the recipient. Two recipients had temporarily elevated transaminases (defined here as acute liver disease) which resolved spontaneously and another two recipients showed a persistent elevation of liver function tests but were clinically asymptomatic. Symptoms of $\mathrm{HCV}$ infection may range from asymptomatic viraemia to cirrhosis and liver failure, and disease may require a long time to develop. The number of patients exposed to the risk of $\mathrm{HCV}$ infection in this study was small and follow-up time was between 4 and 72 months. Therefore, the lack of severe consequences within this relatively short observation period after virus transmission does not 
permit the prediction of future disease development. However, it shows that kidneys and hearts from HCVpositive donors can be transplanted successfully without causing serious short-term effects.

While it has become standard practice to accept organs from $\mathrm{HCV}$-positive donors for life-saving emergency indications in liver, lung and heart transplantation, further specific use of these organs-as in anti-HCV-positive recipients or transplant candidates with predictable limited life expectancy-has to be evaluated. In countries with a high prevalence of anti$\mathrm{HCV}$ in the general population, the option of transplantation of organs from anti-HCV-positive donors to anti-HCV-positive recipients has to be examined. Preliminary results from a retrospective study in kidney recipients ${ }^{17}$ indicate that anti-HCV-positive kidneys can be transplanted safely into anti-HCVpositive recipients. On the other hand, the long-term follow-up under the influence of chronic immunosuppression remains unknown. It has also to be considered that the anti-HCV antibodies detected by the currently used tests do not confer immunity ${ }^{18}$ and

\section{References}

1. Ho M. Hepatitis C virus. Another agent transmitted by transplanted organs. $N$ Engl J Med 1991; 325: 507-509.

2. Choo QL, Kuo G, Weiner AJ, Overby LR, Bradley DW, Houghton $\mathrm{M}$. Isolation of a cDNA clone derived from a blood-borne non-A, non-B viral hepatitis genome. Science $1989 ; 244$ : 359-362.

3. Pereira BJ, Milford EL, Kirkman RL, Levey AS. Transmission of hepatitis $\mathrm{C}$ virus by organ transplantation. $N$ Engl J Med 1991; 325: 454-460.

4. Roth D, Fernandez JA, Burke GW, Esquenazi V, Miller J. Detection of antibody to hepatitis C virus in renal transplant recipients. Transplantation $1991 ; 51: 396-400$.

5. Pereira BJ, Milford EL, Kirkman Ret al. Prevalence of hepatitis $C$ virus RNA in organ donors positive for hepatitis $C$ antibody and in the recipients of their organs. $N$ Engl $J$ Med 1992; 327: 910-915.

6. Aymard JP, Botte C, Contal P, Janot C, Streiff F. Seroprevalence des anticorps contre le virus de l'hepatite $C$ chez les donneurs de sang. Etude des tests ELISA et RIBA de 2 e generation et des marqueurs indirects Pathol Biol Paris 1993; 41 : 149-153.

7. Zhang YY, Guo LS, Hao LJ, Hansson BG, Widell A, Nordenfelt E. Antibodies to hepatitis $\mathrm{C}$ virus and hepatitis $\mathrm{C}$ virus RNA in Chinese blood donors determined by ELISA, recombinant immunoblot assay and polymerase chain reaction. Chin Med J [Eng] 1993; 106: 171-174.

8. Hassan NF, Kotkat A. Prevalence of antibodies to hepatitis C virus in pregnant women in Egypt. J Infect Dis 1993; 168: 248-249.

9. Hadziyannis SJ, Giannoulis G, Hadziyannis E et al. Hepatitis C virus infection in Greece and its role in chronic liver disease too little is still known about superinfection with different prognostically relevant genotypes ${ }^{19}$ of $\mathrm{HCV}$.

In the light of the natural history of $\mathrm{HCV}$ infection, the shortage of donor organs and the increasing number of transplant candidates with assumed limited life expectancy, the routine use of $\mathrm{HCV}$-positive donor organs has been debated. ${ }^{20}$ To our knowledge, the deliberate use of organs from donors with confirmed $\mathrm{HCV}$ infection has yet to be reported. To some extent, the problem is comparable to other compromises made as a consequence of donor organ shortage, such as extending criteria for donor organ suitability (e.g., age, fatty livers). The consequent potential risk to the recipient may be considered acceptable.

In conclusion, this study shows that HCV prevalence in the donor pool was $1.9 \%$ and that with a confirmed anti-HCV test the rate of anti-HCV positive but PCR negative test results was as low as $0.5 \%$. De novo $\mathrm{HCV}$ infection was proven in four of eight organ recipients at risk, and mild chronic liver disease developed in two of these infected patients whereas no other serious complications were observed. and hepatocellular carcinoma. $J$ Hepatol 1993; 17 Suppl 3: S72-S77.

10. Quiroga J, Martin M, Pernas M et al. Serological study of the immune response to the NS5 region of different $\mathrm{HCV}$ infections. J Hepatol 1993; 18 Suppl 1: S30.

11. Garson JA, Ring C, Tuke P, Tedder RS. Enhanced detection by PCR of hepatitis C virus RNA. Lancet 1990; 336: 878-879.

12. Alter MJ, Margolis HS, Krawczynski $\mathrm{K}$ et al. The natural history of community acquired hepatitis $\mathrm{C}$ in the United States. [The sentinel counties chronic non-A, non-B hepatitis study team] $N$ Engl J Med 1992; 327: 1899-1905.

13. Esteban R. Epidemiology of hepatitis $\mathrm{C}$ virus infection. $J$ Hepatol 1993; 17 Suppl 3: S67-S71.

14. Grob PJ, Joller-Jemelka HJ. Hepatitis-C-virus (HCV), antiHCV und non-A-, non-B-hepatitis. Schweiz Med Wochenschr 1990; 120: 117-124.

15. Alter HJ. New kit on the block : evaluation of second-generation assays for detection of antibody to the hepatitis $\mathrm{C}$ virus. Hepatology 1992; 15: 350-353.

16. Poterucha JJ, Rakela J, Lumeng L, Lee $\mathrm{CH}$, Taswell HF, Wiesner RH Diagnosis of chronic hepatitis $\mathrm{C}$ after liver transplantation by the detection of viral sequences with polymerase chain reaction. Hepatology $1992 ; 15: 42-45$.

17. Morales JM, Andres A, Campistol JM. Hepatitis C virus and organ transplantation. $N$ Engl J Med $1993 ; 328 ; 511-513$.

18. Farci $\mathrm{P}$, Alter HJ, Govindarajan S et al. Lack of protective immunity against reinfection with hepatitis $\mathrm{C}$ virus. Science 1992; 258: 135-140.

19. Féray C, Gigou M, Samuel D et al. Direct evidence for a more pathogenic effect of HCV type II: the model of liver transplantation. $J$ Hepatol 1993; 28 Suppl 1: S4

20. Aswad S, Mendez R, Weingart RG, Mendez R. Expanding organ availability by using hepatitis $\mathrm{C}$ antibody positive donors. Transplant Proc 1993; $25: 2270-2271$. 